\title{
Mekong River Basin International Cooperation: The Organizational and Geopolitical Mobilizations
}

\author{
Wanjing Feng ${ }^{1, \dagger}$, Zhixin $\mathrm{Lei}^{2, *},{ }^{*}$, Ziyu Zhou ${ }^{3, \dagger}$ \\ ${ }^{1}$ Southwestern University of Finance and Economics, Chengdu, Sichuan Province, China \\ ${ }^{2}$ Economic Department of Art and Science, Waco, Taxes, US \\ ${ }^{3}$ Government and International Studies, Hong Kong Baptist University, Hong Kong, Hong Kong SAR, China \\ ${ }^{*}$ Corresponding author. Email: ${ }^{2}$ Zhixin_lei2@baylor.edu \\ ${ }^{\dagger}$ These authors contributed equally.
}

\begin{abstract}
An important example of international cooperation in watershed development is in the Mekong River basin. There has been the entanglement of various forces for nearly a century, as well as the continuous strengthening of international cooperation. After getting rid of the occupation of European countries, the four lower Mekong countries began to develop independently one after another. As the most important transnational water system in Asia, the Mekong River is not only dependent on the development of countries in the river basin but also a good opportunity to establish global international relations. France, the United States, Japan and other countries have participated in the investment of watershed management. Mekong River Commission is the most important international organization in river basin governance. It focuses on the reform of management functions, transfers water resources utilization and some core management functions to the national Mekong River Commission (NHC), changes the operation mechanism, draws lessons from the concept of ASEAN, and tries to lead regional water resources affairs. However, due to its limited financial and human resources, the Mekong River Commission had to seek cooperation between different institutions and mechanisms and area. This would depend on the state of water resources of the Mekong River commission management performance of the Mekong River Commission, development partners, international multilateral organizations (Asian Bank and the World Bank) and Lancang-Mekong cooperation attitude and action. Therefore the question of how the river should be managed, and how countries inside and outside the basin should co-operate, has been hotly debated until now. This paper introduces the development status of the Mekong River in recent years and discusses the different viewpoints of scholars from different countries in terms of the Mekong River Commission and China's Lancang-Mekong Action.
\end{abstract}

Keywords: Mekong River, history, the Mekong River Commission (MRC), regional cooperation.

\section{INTRODUCTION}

The Mekong River is the longest river in Southeast Asia spanning around 4,350 kilometers. The main tributaries of the Mekong River originate in Qinghai province in southeastern China and flow east through Tibet and Yunnan province, forming the international border between Myanmar and Laos and the border between Laos and Thailand. The river flows through Laos, Cambodia, and Vietnam before it drains its waters in the South China Sea. More than three quarters of the drainage area of the Mekong River lies within four countries namely, Laos, Thailand, Cambodia, and Vietnam in its lower course [11]. The river is a major contributor to the economic development of the region, including agriculture, hydropower, fishing and transportation. Many of the people who live along the river are engaged in agriculture with rice farming being the major crop.

The Lancang-Mekong Cooperation (LMC) mechanism is a dialogue and cooperation mechanism for six countries to implement sustainable development and carry out mutually beneficial and pragmatic cooperation along the Lancang-Mekong River. In March 2016, the first Lancang-Mekong Cooperation Leaders' Meeting was held in Sanya, China. Two important documents, the Sanya Declaration of the First Lancang-Mekong Cooperation Leaders' Meeting and the Joint Statement on 
Production Capacity Cooperation among LancangMekong Countries were issued at the meeting, which achieved positive outcomes. The Second LancangMekong Cooperation (LMC) Leaders' Meeting held in Cambodia in January 2018 issued the Five-year Action Plan for Lancang-Mekong Cooperation (2018-2022) and the Phnom Penh Declaration of the Second LancangMekong Cooperation (LMC) Leaders' Meeting.

In recent years, Myanmar's economy has developed rapidly, with GDP growth at around 7\%. In 2018, bilateral trade between China and Myanmar reached 15.24 billion US dollars, an increase of $13.1 \%$. The number between China and Laos reached $\$ 3.47$ billion, an increase of $15 \%$. Between China and Thailand was $\$ 87.5$ billion, an increase of $9.2 \%$. Bilateral trade volume between China and Cambodia reached 7.4 billion US dollars, an increase of $27.6 \%$. Among them, with Vietnam reached $\$ 147.9$ billion, an increase of $21.2 \%$. According to the data, the establishment of the LancangMekong Cooperation mechanism has resulted in increased cooperation among countries in the basin and a steady improvement in economic status[1].

\section{SCHOLAR'S POINT OF VIEW}

Despite the overall importance of the river, various scholars have expressed their different thoughts and opinions on the various human-made activities on the river and their positive and negative impacts. This paper will explore the various views of different scholars concerning the Mekong River.

\subsection{History of Mekong river}

One of the key scholars who has explored the impact of the Mekong River is Ly Kesa in her article "Hydropower Development, Economic Growth and Social Equality: Mekong Region". Mekong River has been used for various hydroelectric power projects which had a positive impact on the growth of the region [2]. However, the various projects have had both positive and negative impacts. As the demand for power in the region grows, the need for the construction of more hydropower plants grows. By generating more electricity in the region, the power has been integral for spurring economic growth in the region. However, the emergence of these hydroelectric power plants has had its negative attributes. According to Kesa, 2014, the power projects have the potential to destroy the wetland eco-systems and negatively affect the quality of the water [2]. One of the major negative impacts has been the destruction of fish resources thereby affecting the livelihoods of more than 60 million people on the Lower Mekong Basin. Cambodia and Laos are the major countries impacted by these developments since the majority of their people's livelihoods depend on the river's resources. The river basin is home to indigenous groups of people mostly found around the Se San and Se Kong area and any activities upstream, put the livelihoods of these communities in jeopardy. Finally, the construction of the major dam projects in the area has led to an increase in floods in the areas [3]. For example, many Cambodians have lost their lives through floods caused by test operations of the hydropower projects upstream [2]. Many have also lost their properties as well as the increased spread of diseases which are related to deteriorating water quality in the area.

All the nations within the Mekong River have different agendas when it comes to the utilization of the various resources and many scholars have seen this as one of the major potential reasons for conflict. China has constructed dams for hydropower and irrigation. China feels that the dams benefit the countries downstream [4]. On the other hand, the countries downstream feel that China's activity poses a huge threat due to its grip and control of the Upper Mekong flow. Since 1993, China has built six dams which is a move that has nee questioned by the other countries. The various countries have not agreed on the way forward when it comes to future developments. For example, in 2013 Laos was in the process of constructing the Xayaburi dam with more plans to make a further dam in 2014. The construction of these DAMS is considered controversial by various countries, as expressed by various groups. Various environmental groups have also expressed concern that it could affect fisheries, food security and the livelihoods of 65 million people [4]. It argues that after the construction of these dams, it would be hard to control the other nations from undertaking such projects which would yield more challenges in the area.

Many scholars around the world believe that fair distribution of Mekong resources can boost economic growth in the six countries [5]. The 6 countries sharing these resources are within the developing nation category with a GDP of around \$2,570 as per 2019 statistics. Many of the countries downstream still rely on the traditional agricultural methods which are ineffective. However, due to the modernization of its agricultural sectors such as the use of fertilizers and irrigation, Thailand has been able to convert the Mekong resources which have made it one of the leading rice producers in the world. Thai rice yields around 4.5 tons for every hectare. On the other hand, Cambodia is one of the poorest countries in the region with rice production of under 2 tons for every hectare. According to Gildea, 2014, investing in more technology can be integral in revolutionizing agriculture and utilizing the Mekong River resources which would be integral in improving the total welfare of the region.

\subsection{Views on the early Mekong River Commission}

Scholars from all countries support that rational use of Mekong resources can drive the development of 
downstream countries. The six Mekong countries are all developing countries. With a per capita gross national income of $\$ 2,570$ in 2019, Laos is one of the poorest countries in Asia. In the downstream four countries, 80 to 85 percent of the population is engaged in agriculture, still using traditional irrigation methods, which are inefficient and low-yield. Thailand invested more in fertilizers and irrigation, resulting in higher yields than other countries. Thai rice yields are estimated at 4.5 tons/hectare, while in Cambodia yields are near two tons/hectare [6]. Therefore, investing technology and capital in rational utilization of Mekong water resources can better develop agriculture and improve people's livelihood. But there are questions about how to make the best use of the Mekong's water resources, whether or to how many dams should be built on main and tributaries, and whether accepting foreign investment and technical assistance will affect international relations. So, there are some different opinions among scholars about the early work of the Mekong River Commission.

Jeffery W. Jacobs, an American scholar, states that the objectives, structure and program of the MRC are appropriate [7]. He sees the MRC as more than just a dam-building body, focusing on social and environmental aspects and mitigating social and environmental costs. Jeffery W. Jacobs affirmed that the MRC is highly flexible and can make adjustments according to the changing situation. The Mekong project was seen by some as the region's 'Marshall Plan' [6]. In the mid-20th century, France invested in the development of the Mekong River basin in an attempt to rebuild the French Federation of Indochina. Although the United States supported Indochina's desire for independence, it was experiencing the Cold War at that time. They were worried that the victory of China's liberation war would further enhance the Soviet Union's control over the world So, they provided financial and technical support to some Asian countries along the Mekong River to establish diplomacy. Therefore, some Scholars in the US believe that the absence of China and Myanmar in the MRC will enable downstream countries to receive more support funds and achieve better development. They hold a supportive attitude towards the investment of the US, believing that this will greatly help downstream countries to establish relationships and achieve harmonious development.

But many academics disagree, fearing that the MRC has ignored social issues and is generally concerned about over-exploitation of hydropower. David Karonen, a senior fellow at the Stimson Institute, said Dams in the mainstream would not only damage the basin's hydrology, ecology, fisheries and food production but also increase tensions between upstream and downstream countries and undermine regional peace. Some scholars also believed that MRC was "institutionalized neglect of Environmental and social issues" [8]. British political scientists pointed out the problems of the MRC:
First, NGOs failed to participate in the official process.

Second, the MRC is driven by international donor initiatives and does not reflect the management capacity and development concerns of the governments of the basin countries. The Mekong River Commission's development partners are those sponsors. Before 2016, these countries basically dominated the agenda and activities of the Mekong River Commission by virtue of their funding and knowledge advantages. Some scholars even pointed out that the Mekong River Commission had become "a convenient carrier" or "secretariat" for sponsors to carry out funding and projects. The MRC's project-based mechanism is also designed to facilitate funding and project requirements from development partners. In addition, although sponsors dominate the agenda and activities of the MRC, the decision-making process of the MRC and the member states are irrelevant and parallel. So, the experience and knowledge gained at the regional level can hardly be translated into practical actions of the member states.

Third, all the members of the MRC hope to achieve their own economic development through the organization, while putting regional public interests on the back burner. Finnish scholar Marco Keskeeler and others argue that seeing the Mekong as "a successful example of international river management" is too optimistic because "it still faces many constraints, such as the absence of upstream China and Myanmar". Contrary to the views of American scholars, he does not think that China and Myanmar would hinder the governance of the MRC but states that the upstream and downstream countries should work together. John Doll and Kate Lazarus, senior water experts at the Australian Agency for International Development, noted that "Councils are often absent from or silent about substantive decisions on watershed water development. The Secretariat has little involvement and very limited information on upstream Chinese hydropower development on the mainstream and Laos and Vietnam hydropower development on tributaries ". Based on the MRC, the four downstream countries also established national MRC. There are only a few board meetings held by the MRC council each year, and all the meetings are attended by members of the national MRC from four countries. There are obvious conflicts between different departments, and coordination is very difficult to achieve comprehensive management. Therefore, the "sectoral interests" represented by the MRC are not necessarily the highest national interest or the "overall interest of the basin". In addition, members-only focus on their own river basins, without upstream China and Myanmar, so the cooperation is not thorough enough. That's why some scholars argue that "a new water management regime is needed in the Mekong region to help societies make better choices about how water is shared and managed". 


\subsection{Whether the situation changes: the Lancang-Mekong Cooperation after 2014}

As mentioned in previous sections, the existed Mekong cooperation in the 1990s neither handled the problems of interest conflicts efficiently, nor did it include some essential stakeholders along the basin, namely China and Myanmar. When it came to the 21st century, a new possible event that might contribute to the conflict-solving process of the Mekong Basin is the establishment of the Lancang-Mekong Cooperation (LMC), which was first introduced by the Chinese Prime Minister Li Keqiang at the 17th China-ASEAN summit in 2014, in response to Thailand's initiative of sustainable development of the Lancang-Mekong Sub-region in 2014. Then, in 2016 the 1st LMC leaders' meeting was held in China with the preliminary operation of the LMC mechanism.

For initial purposes, the LMC conducts a "3+5" cooperation framework that takes political and security issues, social-cultural, and people-to-people exchanges, and economics and sustainable development as its three supports. Meanwhile, the cooperation mainly devotes to five aspects: connectivity, cross-border economic cooperation, production capacity, water resources, and agricultural and poverty reduction as its five-priority cooperation direction. Also, there are high-level meetings every year.

To what extent the LMC mechanism can offer the basin with new possibilities in achieving more common and equal benefits remain an issue under discussion among different scholars, among which doubting the actual transformation of the nature of cooperation occupies a certain potion. For some scholars, in a perspective concerning benefits distribution, the socalled "new" framework of cooperating does not put the goal of sustainable water resources into practice to a very high extent, as the country still seeks economic benefits including trade and investment to infrastructural construction along the basin rather ecological values, which should distinguish the new initiative from the old one [9]. Supporting evidence can be found in other academics' analysis that as each of the partners has different primary preferences of goals within the LMC, the cooperation on water resources for the Mekong Subregion somehow is facing huge obstacles [10]. Based on the nature of water resource utilization, hydropower is the main usage compared with any other way. However, in the LMC area, the existed experience indicates that hydropower development has a serious impact on water discharge, fisheries, and the livelihood of basin people. Thus, the potential drawbacks stop the countries from coming up with a more specific and practical consensus on water resources, illustrating the deficient cooperation on their priority goal of sustainable water cooperation.
Besides the approach of distinguishing initiative content, a more political way of assessing the relationship between China and downstream countries is taken into consideration by academics, which is hydro politics. Evidence was shown that just one week before the LMC summit, China released its storage water in Lancang dams to relieve the drought situation of downstream regions, which is widely considered as a way of hydro diplomacy [11]. Meanwhile, the political initiative on hydro discourse China tries to seek to consolidate appears in its actions in dry seasons with targeted sharing water data among the downstream countries. For Middleton and Allouche, this type of "hydro diplomacy" is not coming from an organized framework. Instead, it all depends on China's willingness, which indicates a new structure guided by China on its own [11].

The approach of geopolitics, which contains both of China's ambitions in its leading narrative as well as an institutional counterbalance, shows quite strong explanatory power in the case of the LMC and is discussed by many scholars. Many of the writers discussed how China may be a concern in order to counterbalance the influence from another regional or subregional cooperation summit, while the other focused on explaining how China seeks to actively expand its influence through the LMC, putting which is a bigger transboundary blue map, namely the Belt and Road Initiative (BRI). For those who consider promoting the BRI as the senior goal ahead of the LMC, China finds a new area for more investment using the expenditure from Asian Infrastructure Investment Bank, which is the supportive breach of BRI, to enhance the integration of its backyard that is guided by itself [9]. Similar ideas can be seen from Busbarat et, al.'s work that the effort of China in constructing the LMC offers possibilities to build a more Sinocentric relationship in the Indo-China Peninsula, while later the LMC can be a fundamental infrastructure for the BRI $[12,13]$. Besides a subpart of the BRI, the LMC is also considered as a counterbalance strategy of the Chinese government facing challenges from outsiders apart from the basin, for example, the US. Also mentioned by Busbarat et, al. if outside competitors intervene too much in the Mekong Basin, China's selfbenefits and exclusive influence cannot be built up [11]. At present the balancing situation for China is not so satisfactory as among the Mekong countries, the US and Japan still act as important cooperators with some of them, therefore there is still a long way for China to achieve its objects [14]. But what is fortunate for the country is that since the establishment of the LMC, the role taken by the MRC in economic development is marginalized, indicating the growing influence of Chinese sectors, as well as its declining in times of appearance in the discourses of these members $[14,15]$.

Apart from the transboundary point of view, some ideas from Chinese perspectives are also given. While former opinions advocate the role of China in a more self- 
interest maximized way, the latter ones strengthen the positive significance of the LMC project as a whole [16, 17]. As sustainable water resources are one of the essential areas of cooperation in the basin, the water cooperation in the LMC is guaranteed by high-level, wide-range, and large-quantity of cooperation [18]. Thus, it can fulfill more needs of people in the LancangMekong area. Essentially, it offers institutional protection for climate change and enhances governance capacity, as well as promotes the Lancang-Mekong community with a shared future.

\section{CONCLUSION}

Unlike other successful cases of regional cooperation, Mekong river basin is still seeking its own organizaiotnal solution for its future development. The Mekong River Commission (MRC) has transferred the utilization of water resources and some core management functions to the National Mekong River Commission (NHC), changed the operating mechanism, learned from ASEAN (Association of Southeast Asian Nations) concepts, and tried to lead the regional water resources affairsce of the necessity of altering energy, the process is inevitable and unpreventable for all the countries in the globe. Unfortunately, none of these regional cooperation or organizations provide an satisfactory solution. The current studies show that more effective transformations for the South Asian courtries and their eagerness for winwin situation are urgently needed.

\section{REFERENCES}

[1] Biba, S. (2018). China's 'old' and 'new' Mekong River politics: the Lancang-Mekong Cooperation from a comparative benefit-sharing perspective [Article]. Water International, 43(5), 622-641. https://doi.org/10.1080/02508060.2018.1474610

[2] Busbarat, P., Bunyavejchewin, P., \& Thapiporn, S. (2021). China and Mekong regionalism: A reappraisal of the formation of Lancang-Mekong Cooperation. Asian Politics \& Policy, 13(2), 193211.

https://doi.org/http://dx.doi.org/10.1111/aspp.1257 5

[3] Feng, Y., Wang, W., Suman, D., Yu, S., \& He, D. (2019). Water Cooperation Priorities in the Lancang-Mekong River Basin Based on Cooperative Events Since the Mekong River Commission Establishment [Article]. Chinese Geographical Science, 29(1), 58-69. https://doi.org/10.1007/s11769-019-1016-4

[4] Middleton, C., \& Allouche, J. (2016). Watershed or Powered? Critical Hydropolitics, China and the 'Lancang-Mekong Cooperation Framework'
[Article]. International Spectator, 51(3), 100-117. https://doi.org/10.1080/03932729.2016.1209385

[5] Ren Junlin, Peng, Z., \& Pan, X. (2021). New transboundary water resources cooperation for Greater Mekong Subregion: the Lancang-Mekong Cooperation. Water Policy, 23(3), 684-699. https://doi.org/http://dx.doi.org/10.2166/wp.2021.1 98

[6] Sovinda, P., \& Primiano, C. B. (2021). Explaining China's Lancang-Mekong cooperation as an institutional balancing strategy: dragon guarding the water. Australian Journal of International Affairs, $75(3)$,

323-340. https://doi.org/http://dx.doi.org/10.1080/10357718. 2021.1893266

[7] Williams, J. M. (2021). Is three a crowd? River basin institutions and the governance of the Mekong River [Article]. International Journal of Water Resources Development, 37(4), 720-740. https://doi.org/10.1080/07900627.2019.1700779

[8] Xing, W. (2017). Lancang-Mekong river cooperation and transboundary water governance: A Chinese perspective [Article]. China Quarterly of International Strategic Studies, 3(3), 377-393. https://doi.org/10.1142/S2377740017500233

[9] Feng, Y., Wang, W., Suman, D., Yu, S., \& He, D. (2019). Water cooperation priorities in the LancangMekong River basin based on cooperative events since the Mekong River Commission establishment. Chinese geographical science, 29(1), 58-69.

[10] Gildea, M. (2014). State Water Resource Competition and the Resulting Consequences of Diminished Water Supply. Asia-Pacific Center For Security Studies, 1-24. Retrieved 19 October 2021, from.

[11] Hecht, J. S., Lacombe, G., Arias, M. E., Dang, T. D., \& Piman, T. (2019). Hydropower dams of the Mekong River basin: A review of their hydrological impacts. Journal of Hydrology, 568, 285-300.

[12] Jacobs, J. (1995). Mekong Committee History and Lessons for River Basin Development. The Geographical Journal, 161(2), 135. https://doi.org/10.2307/3059971

[13] Kesa, L. (2014). Hydropower Development, Economic Growth and Social Equality: Mekong Region. S. Rajaratnam School of International Studies.

[14] Klare, M. T. (2020). Climate Change, Water Scarcity, and the Potential for Interstate Conflict in South Asia. Journal of Strategic Security, 13(4), 109-122. 
[15] Morton, L. W., \& Olson, K. R. (2018). The pulses of the Mekong River Basin: Rivers and the livelihoods of farmers and fishers. Journal of Environmental Protection, 9(04), 431.

[16] Pokhrel, Y., Shin, S., Lin, Z., Yamazaki, D., \& Qi, J. (2018). Potential disruption of flood dynamics in the Lower Mekong River basin due to upstream flow regulation. Scientific reports, 8(1), 1-13.

[17] Soukhaphon, A., Baird, I. G., \& Hogan, Z. S. (2021). The impacts of hydropower dams in the Mekong River Basin: A review. Water, 13(3), 265.

[18] Xing Lv (2018). Exploring the Relationship between the Mekong River Commission and External Cooperation 